\title{
(息)
}

Citation:

Uddin, M and Alam, A and Yazdifar, H and Shubita, M (2022) Terrorism, Innovation and Venture Capital. Journal of Economic Studies, 49 (2). pp. 330-345. ISSN 0144-3585 DOI: https://doi.org/10.1108/JES-08-2020-0404

Link to Leeds Beckett Repository record:

https://eprints.leedsbeckett.ac.uk/id/eprint/7510/

Document Version:

Article (Accepted Version)

Creative Commons: Attribution-Noncommercial-No Derivative Works 4.0

The aim of the Leeds Beckett Repository is to provide open access to our research, as required by funder policies and permitted by publishers and copyright law.

The Leeds Beckett repository holds a wide range of publications, each of which has been checked for copyright and the relevant embargo period has been applied by the Research Services team.

We operate on a standard take-down policy. If you are the author or publisher of an output and you would like it removed from the repository, please contact us and we will investigate on a case-by-case basis.

Each thesis in the repository has been cleared where necessary by the author for third party copyright. If you would like a thesis to be removed from the repository or believe there is an issue with copyright, please contact us on openaccess@leedsbeckett.ac.uk and we will investigate on a case-by-case basis. 


\section{Terrorism, Innovation and Venture Capital}

Abstract: This paper examines the relationship between terrorism and innovation and the moderating role of venture capital. Using GMM-IV estimation of panel data from 140 countries covering the period of 2007-2016, we find that terrorism has negative impact on innovation. Interesting results emerge when we separated the developed countries from others. The results show that the impact of terrorism on innovation is lower in developed countries. This is due to the fact that strong institutional settings in developed countries makes the investors confident by providing support and incentives. Better institutional settings in developed countries also helps to reduce uncertainty which maximize innovation and minimize terrorism risk. We also find that venture capital positively moderates the terrorism and innovation relationship. This implies that by providing sufficient fund for technological development, venture capital may help to reduce terrorism risk. These results may guide the policy makers to find a business solution instead of lengthy political solution to mitigate terrorism risk in emerging countries. Overall, this paper will provide the basis for improving the counter-terrorism approaches from innovation perspective.

Key Words: Terrorism, Innovation, Venture capital, Emerging Markets

\section{Introduction:}

Innovation and institutions are closely linked with each other. To promote innovation, proper institutional support is necessary (Choi et al., 2014; Ghazal and Zulkhibri, 2015; Wu et al., 2016). Institutional supports help to create value and ensure return from innovation by providing investor protection, access to external sources of finance, government incentives and supports, and fostering innovation friendly environment. In contrast, institutional failure such as terrorism, political instability, weak rule of law, government inefficiencies hinder innovation performance (Barasa et al., 2017). Terrorism, as an example of institutional failure (Coggins, 2015), has become an important issue all over the world and may affect innovation activities as suggested by Koh (2007). 
There are several reasons why terrorism is considered to be one of the most important issues for innovative activities. First, terrorism stifles investor confidence and tends to reduce expected return from invested capital (Desouza et al., 2007; Bandyopadhyay et al., 2015; Almeida and Montes, 2020). This in turn leads investors to shift their investment in another country. As a result, it reduces a country's stock of productive capital and flow of productivityenhancing technology (Bandyopadhyay et al., 2015). Second, terrorism has direct impact on foreign direct investment (Bandyopadhyay et al., 2014; Shah et al., 2020). This eventually contributes to a shortage of productive foreign capital and also jeopardise the possibility of having high quality technology from foreign countries. Moreover, terrorism may increase cost of innovation by raising business transaction cost (terrorism insurance), interest rates, and opportunity cost. Although there are number of papers that have examined the effect of terrorism on various economic and finance issues, empirical research on effect of terrorism on innovation is very rare. Therefore, this paper examines the relation between terrorism and innovation using terrorism and innovation data from 140 countries.

Institutional difference among the countries greatly influences the level of innovation capability as suggested by Barbosa and Faria (2011). It is argued that stronger institutional settings help to build investor confidence, provide support, security, incentives, and reduce uncertainty (Erbaş, 2004; Laeven, 2014) which maximize innovation while minimize the terrorism risk. To see the effect of institutional quality on terrorism risk, we have separated the developed countries from others as it is assumed that they have relatively stronger institutional environment (Erbaş, 2004) and terrorism threats are reported more frequently in these countries (Blomberg et al. 2004) which might help investors to cope with those threats. Moreover, this paper has examined the role of venture capital in moderating the relationship between terrorism and innovation. It has been argued that venture capital makes the financing easy to the entrepreneurs and therefore should encourage innovative activities (Florida and Kenney, 1988). 
Bertoni and Tykvová (2015) added that support provided by venture capital towards invention and innovation goes well beyond the mere provision of financing such as providing technical know-how to launch new products or building new product markets. In a related study, Kortum and Lerner (2001) found that venture capital contributed around 15\% of industrial innovation in USA. Therefore, it would be interesting to see if the availability of venture capital moderates the relationship between terrorism and innovation.

This paper contributes to the existing literature in several ways. First, most of the previous studies on the link between terrorism and innovation are conceptual in nature (i.e., Koh, 2007). This paper examines the link between terrorism and innovation using quantitative data. Second, our results suggest an important difference between developed countries and others regarding how institutional strength of a country helps to beat the country's terrorism threat. Third, the paper has examined the way venture capital may moderate the relation between terrorism and innovation. The findings of this paper contribute to the policy makers to mitigate terrorism risk and create a sustainable innovation-based economy. Fourth, the paper has used panel data methodology that allows to control the unobserved heterogeneity that may arise from heterogeneous nature of institutional environment among the sample countries.

The paper is organised as follows. Section two presents relevant literature and develops hypotheses relevant to the study. Section three introduces the data and research method and also introduces the variables used in this study. Section four presents the results and associated discussion. Section five presents the conclusion of this study.

\section{Literature review and hypotheses:}

Terrorism has been an issue of concern for businesses and economy and attracted attention of numerous researchers from economics, political science and sociology discipline since 1960s (Sandler, 2014). However, Chesney et al. (2011) mention that research on terrorism from the 
context of economics and finance is relatively scant. Most of the research on terrorism in the area of economics and finance has examined the economic antecedents of terrorism and its effect on financial markets and trade. For example, Blomberg et al. (2004) found negative effect of terrorism on economic growth for both developed and developing countries. Chesney et al. (2011) and Nitsch and Schumacher (2004) confirmed that terrorism has detrimental effects on stock, bond and commodity markets and also on foreign trade. Gupta et al. (2004) pointed out that terrorism may disrupt economic activities, decreases the tax base, reduce the efficiency of tax system and distort the composition of public spending. Authors such as Hobbs et al. (2016) and Aloui and Nguyen (2014) examined the effect of terrorism on stock markets and found that such events have significant negative effects on stock returns. Recently, Mnasri and Nechi (2016) examined the effect of terrorism on emerging market stock returns and found that such events have long lasting effect on stock return in those countries.

Although we have a number of papers that examined the effect of terrorism on growth, foreign direct investments, bilateral trade, fiscal policies, stock market and cost of borrowing, there is a dearth of research linking terrorism with innovation. Terrorism, as an exogenous shock, affects the sentiment of managers, investors and general people (Chen et al., 2020). The intense media coverage about terrorist events causes a substantial negative sentiment effect (Nellis and Savage, 2012). Baumeister et al. (2001) point out that negative events provoke stronger behavioural reaction than positive event. As a result, terrorism related negative sentiment would have strong effect on corporate investment decision (Wang and Young, 2020). Xu (2020) points out that uncertainty affects corporate investment decision by changing the cost of capital. Exogenous shocks such as terrorist attacks create considerable uncertainty and negatively affects investors' sentiment. As a result, cost of equity and cost of debt tend to rise following any exogenous shock that create uncertainty, such as terrorist attack. The rise in cost of capital would affect the irreversible investment as the value of option to wait would increase 
(McDonals and Siegel, 1986). In this context, Xu (2020) point out that on the face of uncertainty, firms would decrease investment in innovation due to rise in cost of capital. Moreover, Chen et al. (2020) points out that terrorist attacks could cause management to become more risk-averse and adopt more cautious and conservative approach. As innovation is treated as risky investment, management may tend to reduce investment in innovation following terrorist events. Although, there are theoretical justifications for an inverse relationship between terrorism and innovation, empirical studies are very rare. Few studies that looked at impact of uncertainty and terrorism on innovation investment include $\mathrm{Xu}$ (2020), Antoniou et al. (2015). These studies find negative effect of terrorism and uncertainty on innovation. Koh (2007) and Desouza et al. (2007) also provide arguments that support negative effect of terrorism on innovation. Based on the above discussion, this paper proposes the following hypothesis:

\section{H1: There is a negative relationship between terrorism and innovation}

The extent and duration of effect of terrorism on economic activities varies depending on the country characteristic. Mnasri and Nechi (2016) point out that effects of terrorism in developed markets tend to be smaller and lasts for relatively shorter period of time due to well established institutions and financial system. Cinar (2017) has provided evidence that terrorism negatively affect economic growth of all countries but the effect is larger and significant to the developing countries compared to developed countries. Similarly, Procasky and Ujah (2016) found evidence that terrorism threat increases cost of debt more in developing countries compared to developed markets. Tingbani et al. (2018) stated that the effect of terrorism would be more pronounced in developing countries compared to developed countries due to scarcity of resources and institutional fragility. In this regard, Sandler and Enders (2008) commented that developed countries are more capable of minimising terrorism thread as they have more resources to implement monetary, fiscal and other relevant policies. Supporting the differential 
effect of terrorism on developed and developing countries, Mnasri and Nechi (2016) stated that developed countries take various corrective measures immediately after the terrorist attacks to smooth the negative effect of any such event. Unlike the developing countries, developed countries have efficient economic and financial institutions to implement those corrective measures to neutralise the effect. The authors also have pointed out that negative effects of terrorist threats in developing countries are generally higher as the institutions are weaker (Uddin et al., 2018) and not capable to support any corrective measure from the government (Khanna and Palepu, 2005). Based on the above theoretical arguments and empirical evidence, this paper proposes the following hypothesis:

H2: Terrorism has insignificant impact on innovation in developed countries.

A number of researches so far has supported the notion that terrorism adversely affects the overall economy (Ehie and Olibe, 2010). As a consequence, innovation may also get affected by terrorist activities. For example, Koh (2007) argued that following terrorist events, government might increase investments in anti-terrorist activities and move substantial funds from economically productive usage. This essentially put negative pressure on innovation. Using crowding out effect of anti-terrorist investments, Desouza et al. (2007) have also pointed out the negative effect of terrorism on innovation of a country. Given the crucial role of innovation on economic growth and development (Alam et al., 2017; 2019), it is important to find out ways to mitigate the adverse effect of terrorism on innovation. Using opportunity cost of terrorism, Freytag et al. (2011) have argued that terrorists as rational actors (Caplan, 2006) consider a sort of cost benefit analysis in making decision to engage in terrorism activities. The benefits from terrorism might include redistribution of power and wealth in the long run through forceful and violent activities (Frey and Luechinger, 2003) while costs might include loss of income, reduced economic activities, loss of social welfare among others. If there is 
sufficient income opportunities and overall growth and development of the economy is higher, then the opportunity cost of terrorism would be higher and this higher opportunity cost would automatically discourage people to engage in terrorist activities which eventually helps to enhance innovation within the economy.

Increasing the opportunity cost of terrorism requires investments in innovative projects that are indispensable to increase the economic growth and development. Use of venture capital is one of the best possible options to inspire the innovation as suggested by Dutta and Folta (2016). Venture capital supports innovation by signalling quality of investment and providing strong network of potential partners, improving the governance of venture backed firms and ensuring timely completion of innovation activities. Sun et al. (2019) pointed out that venture capital supports innovation both in developed and developing markets. Bartzokas and Mani (2004) pointed out that venture capital supports innovation by providing various services such as financial planning, hiring the right human resources, obtaining suitable sources of debt financing, establishing network with foreign firms and obtaining public listing. Therefore, greater availability of venture capital promotes innovation activities. Based on the empirical evidence in support of strong positive effect of venture capital on the growth of innovation, it has been assumed that venture capital may moderate the relationship between terrorism and innovation in a positive way. Therefore, our third hypothesis is:

H3: Venture capital positively moderates the relation between terrorism and innovation.

\section{Data and Methods}

\subsection{Data}

We have used country level data to examine the relation between terrorism and innovation. The main source of data is the global competitiveness index which is produced by the World 
Economic Forum. Owing to data availability and to minimise gaps in the latest data, the chosen sample of 140 countries covering the period 2007 to 2016 have been used. In order to be included in the sample, countries must have at least five consecutive years of data which are available between above mentioned period. At least five consecutive years data have been chosen to control the short panel bias (see Flannery and Hankins, 2013). We have used unbalanced panel sample as it controls survivorship bias while accounts for unobserved heterogeneity (Carpenter and Petersen, 2002). Data were analysed by using STATA 15 software.

All of the variables are measured following global competitiveness index. In this study, dependent variable is innovation which includes company's innovative capacity, quality of scientific research institutions, company spending on R\&D, university-industry collaboration in $\mathrm{R} \& \mathrm{D}$, government procurements of advance technological products, and availability of scientists and researchers which is measured in 7-point scale (1=least innovation activities; $7=$ highest innovation activities). Terrorism costs measures to what extent does the threat of terrorism impose costs on business which is weighted in 7-point scale $(1=$ highest business costs of terrorism; $7=$ least business costs of terrorism). Dummy for availability of venture capital which measures the easiness to start-up entrepreneurs with innovative but risky projects to obtain equity and investor protection which measures the shareholder protection are higher than the median is equal to 1 , and otherwise 0 . FDI and technology transfer define the extent of FDI bring new technology to a country which is measured in 7-point scale $(1=$ least FDI and technology transfer; 7=highest FDI \& technology transfer). Government effectiveness measures the efficiency of the government which is ranked in 7-point scale $(1=$ poorest effective government; $7=$ strongest effective government). Legal system defines the protections of borrowers and lenders legal rights which is measured in 12-point scale $(0=$ poorest legal rights; $12=$ strongest legal rights $)$. Easy access to loan measures the easiness 
to obtain a loan which is rated in 7-point scale ( $1=$ difficult access to loan; $7=$ easiest access to loan). Financial market development measures the development of a market which is ranked in 7-point scale ( $1=$ least development of the market; 7=highest development of market).

Table 1 shows descriptive statistics of our main dependent variable and other selected independent variables.

\section{Please insert Table 1 about here}

To test the collinearity among the variables, we have calculated the correlation matrix presented in table 2 . All of the correlation coefficients are below or close to 0.80 which confirm that the models are free from multi-collinearity (See Archambeaut and DeZoort, 2001; PuchetaMartinez et al., 2018). Variance inflation factors (VIF) have also been calculated to examine the multi-collinearity. The VIF values less than threshold 10 indicate that there is no multicollinearity problem (Archambeaut and DeZoort, 2001; Pucheta-Martinez et al., 2018). The correlation matrix indicates significant pairwise correlation between innovation and explanatory variables. Interestingly, innovation and terrorism are negatively correlated which is consistent with our theoretical argument.

\section{Please insert Table 2 about here}

\subsection{Model}

In order to examine the hypotheses, the following models were devised.

$$
\begin{aligned}
& \text { Innovation } \left._{i t}=\alpha_{i}+\beta_{1}\left(\text { Terrorism }_{i t}\right)+\beta_{2} \text { (Intellectual property rights }{ }_{i t}\right)+\beta_{3} \text { (Government effectiveness } \\
& \left.{ }_{i t}\right)+\beta_{4}\left(\text { Legal system }_{i t}\right)+\beta_{5}\left(\text { FDI and technology transfer }{ }_{i t}\right)+\beta_{6}\left(\text { Easy access to loan }_{i t}\right)+\beta_{7} \\
& \left(\text { Investor protection }_{i t}\right)+\beta_{8}\left(\text { Financial market development }{ }_{i t}\right)+c_{i}+v_{i t}
\end{aligned}
$$




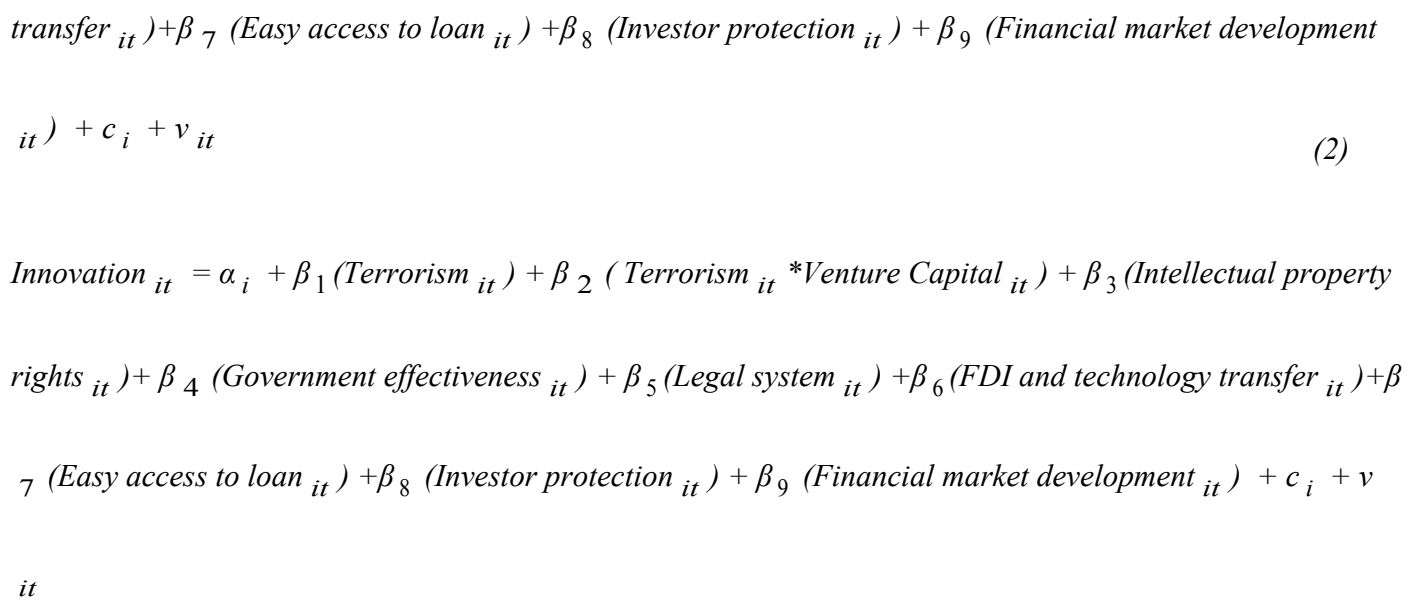

where subscript $i$ represents the country and t represents the year. Here $\alpha_{i}$, and $\beta_{1}$ to $\beta_{9}$ represent the relationships between innovation and terrorism, venture capital, intellectual property rights, government effectiveness, legal systems and FDI and technology transfer, easy access to loan, investor protection, and financial market development. The error component $\varepsilon_{i t}$ it is separated into two components $\varepsilon_{i t}=\mathrm{c}_{i}+\mathrm{v}_{i t}$. The country dummy $\mathrm{c}_{i}$ captures countryspecific effects. Moreover, $\mathrm{v}_{i t}$ is considered as a random disturbance term which is assumed to be i.i.d. normal.

\subsection{Methods}

Endogeneity problem may arise because of the possibility that innovation (dependent variable) also explains the intellectual property rights as higher innovation may motivate firms for intellectual property rights to get first mover advantage and prevent imitation. Endogeneity can also arise as a result of measurement error and omitted variables (Alam et al., 2017; 2019). The presence of endogeneity problem may cause the results from OLS regressions to be biased. Therefore, to control the endogeneity problem, this study used a 2-step Generalized Methods of Moment (GMM) approach. Although endogeneity problem could be controlled by using instrumental variable (IV) approach, GMM estimation is more efficient and popular to address 
this problem (Worrall and Kovandzic, 2010). Moreover, Worrall (2008) stated that, within a single framework, GMM nests several estimations, such as OLS, 2SLS and IV. However, one major issue of using the GMM technique is to finding the valid and relevant instruments. In particular, it is more complex to find and establishing valid and relevant external instruments because external instruments may not be readily available (Pindado et al., 2014; Liu et al., 2015). However, based on available data of this study, the intellectual property rights are instrumented with number of patent applications per million and favouritism of decisions of government officials. The main motivation for selecting these instruments is that both can directly influence to obtain the intellectual property rights. In addition, to assess the instruments validity and relevance, we employed specification tests such as Kleibergen-Paap rk LM test of under-identification indicates that the excluded instruments predict the endogenous variable, i.e. whether the instruments are relevant are significant at $1 \%$ level; Kleibergen-Paap Wald rk F test of weak-identification used to test the presence of weak instruments are more than the size of the usual rule of thumb 10; Hansen J statistic of over-identifying restrictions was used to test whether the instruments are valid, i.e. uncorrelated with the error terms are well above $1 \%$ significant level. The results confirmed that the instruments were used in the models are valid and relevant.

\section{Results and Discussion}

Table 3 presents the empirical results of GMM-IV estimation. In model (1), it shows that there is a significant negative relation between terrorism and innovation. With one-unit change in terrorism, innovation investment decreases by 0.0579 . This result confirms the conceptual prediction of Koh (2007) who stated that terrorism would have a negative effect on innovation. This result is also in line of the findings of Abadie and Gardeazabal (2008) and Arin et al. (2008) who mentioned that terrorism increases the uncertainty, destabilise the financial market and discourage investment by decreasing the return on investment. The result is also in 
conformity of the prediction that terrorism discourages innovation by reducing the innovation performance as suggested by Barasa et al. (2017). Therefore, the results strongly support Hypothesis 1.

In model (2), we include an interaction between terrorism and a dummy for developed country to test whether the effects of terrorism on innovation differ between developed and developing countries $^{1}$. Interestingly, statistically insignificant negative coefficient of the interaction term suggests that impact of terrorism on innovation is lower in developed countries. In other words, terrorism is matter for innovation in developing countries. The reason is that developed countries provide higher investor protection which increases the investor confidence to invest in innovation activities. In this regard, Levine (1997) and Procasky and Ujay (2016) stated that due to higher resources, greater access to finance, and political stability, developed nations can better mitigate to terrorism risk than developing countries. Similar results were obtained by Blomberg et al. (2004) who stated that terrorism has negative but insignificant impact on economic growth in advanced countries. Thus, the results strongly support Hypothesis 2. In model (3), to get further insights how country's economic conditions influence terrorism activities, we separated the sample from high income to low one following World Bank (2021) list ${ }^{2}$. The results show that high income countries tend to reduce terrorism risk more compared to low-income countries. This is due the fact that higher level of income reduces the feeling of deprivation and frustration which in turn reduce violent activities such as terrorism. On the other hand, low-income countries have less ability to formulate more adequate and long-term strategies against violent activities such as terrorism due to their insufficient income to support such programmes.

\footnotetext{
${ }^{1}$ To examine that developed and developing sample coefficients are different, following Procasky and Ujah (2016) we also conducted Chow test, interacting a dummy for developed country with all regressor. The F-test statistics of 360.06 failed to accept null hypothesis that the coefficients are same.

${ }^{2}$ https://en.wikipedia.org/wiki/World_Bank_high-income_economy
} 
In model (4), the interaction terms of the venture capital are added. Terrorism is interacted with availability of venture capital. The positive coefficient on the interaction term suggests that venture capital has a significant influence on reducing terrorism risk by supporting innovation performance. Koh (2007) stated that providing sufficient fund for technological development, venture capital may address the risk of terrorism. Moreover, venture capital investment in technologies may help government or agency to monitor potential terrorists and automatically identify and remove terrorists' activities. Moreover, by financing in responsive R\&D projects, venture capital may increase employment which reduce frustration and feeling of deprivation that might reduce terrorist activities. Thus, the results support the hypothesis 3 .

\section{Please insert Table 3 about here}

All other control variables except financial market development are in line with the expectation. The results show that there is a negative relationship between financial market development and innovation. As most of the sample countries are from developing countries where financial market is still underdeveloped may cause this negative relation. The results show that intellectual property right and innovation is positively related. This implies that higher intellectual property right motivates higher innovation in a country. In a related study, Manzini and Lazzarotti (2016) stated that intellectual property right encourages firms for collaborative product development by protecting their critical technology and innovation. The results also show that FDI and technology transfer is positively related to innovation. This implies that FDI and technology transfer facilitates the use of upgraded technologies, which helps to increase productivity and fosters innovation. Our finding is in line with others such as Cheung and Lin (2004) who also found similar results. The results in this paper also confirm that ease of access to loan has poistive and significant effect on innovation. This is due to the fact that internal fund is naturally limited and issuing new equity may be costly and often unwanted (Hottenrott and Peters, 2012). Therefore, easy accessibility of loan encourages 
increased level of innovative activities by enabling firms to reduce its dependence on scarce internal fund and costly equity issue. The results also suggest that investor protection of a country have significant impact on innovation. Similar results were also obtained by Brown et al. (2013) and Iturriaga and López-Millán (2017). It has been argued by Brown et al. (2013) that strict investor protection leads to better chance of accessing external equity market at a cheaper cost and therefore, firms can afford to make more investments in innovation activities.

\section{Robustness Test}

To test the robustness of our results, pooled Ordinary Least Square (OLS) regression estimation has been applied. Before applying pooled OLS, we performed panel cointegration test. Table 4 presents the panel co-integration test. Among the existing number of approaches such as Kao, Pedroni, and Westerlund tests, earlier one was chosen as it is comprehensive. Moreover, both Pedroni and Westerlund do not work when regressor more than 7 while we have 9 regressor. The null hypothesis of Kao test is that panels are not cointegrated. In Kao test, there are 5 tests included. The results shows that 4 out of 5 tests rejected the null hypotheses which is satisfactory meaning that panels are cointegrated.

\section{Please insert Table 4 about here}

Table 5 reports the results of pooled OLS estimation. In order to control for heteroscedasticity and autocorrelation, a cluster-robust standard error was used following Alam et al. (2017). All the results in Models 5, 6, 7 and 8 are similar to those for GMM-IV estimation. Model 5 shows that terrorism negatively affects innovation for the whole sample countries. In model 6 , the interaction between terrorism and developed country has a positive coefficient which is statistically significant. This again confirms our notion that stronger institutional quality in developed countries help to mitigate the effect of terrorism on innovation activities in those countries. Model 7 confirms that high income countries reduce the terrorism risk. Model 8 
again confirms the positive and significant moderating effect of venture capital on innovation activities. As we can see from the results, the terrorism-innovation relationship becomes positive and significant for all sample countries when venture capital comes into play. In other words, higher innovative activity supported by venture capital investments provides positive signals to investors and brings trust and confidence which reduce extremist activities like terrorism. Other variables including intellectual property right, government effectiveness, legal system, FDI and technology transfer, access to loan and investor protection retain the same sign as the original findings. Therefore, we can conclude that the results are robust and fully support Hypotheses 1, 2, and 3.

\section{Please insert Table 5 about here}

\section{Conclusion}

There is a general consensus in the literature that terrorism has detrimental effect on all aspects of economic activities. However, the effect of terrorism on innovation has not attracted enough attention so far. Using terrorism and innovation data from 140 countries and applying GMMIV estimation method, we find that terrorism has negative effect on innovation. This is due to the fact that terrorism increases the uncertainty in the financial market and provides negative signal to both local and foreign investors. Interesting results emerge when we separate the developed countries from others. The results show that the negative effect of terrorism on innovation disappears for developed countries. This may be due to the fact that developed countries are rich in financial resources which can be used effectively to reduce terrorism risk and stronger institutions in those countries such as legal protection, intellectual property rights, developed financial markets and effective monetary and fiscal policies help those countries to ensure proper allocation of resources to combat terrorism risk and terrorism activities. We also find that availability of venture capital positively moderates the relation between terrorism and 
innovation. This implies that availability of venture capital helps the firm to continue their innovation despite the risk of terrorism in the market. Venture capital is a great source of finance for new and risky innovative ventures. It is popular as it provides strong monitoring and network facilities to the users. It is particularly useful for the users in developing countries where the institutions are fragile. As a result, increased use of venture capital increases the probability of success for the new and risky ventures at the micro level and economic growth at the macro level. This eventually leads to an increase in opportunity cost of engaging in terrorist activities. As a result, increased level of availability and use of venture capital may be good economic solution to the terrorism problem. This is an important finding as this clearly shows that terrorism risk and terrorism activities can be controlled by providing institutional support to venture capitalists and encouraging more and more new entrepreneurs to use venture capital. 


\section{References}

Abadie, A., and Gardeazabal, J. (2008), "Terrorism and the world economy". European Economic Revew, Vol. 52, pp. 1-27.

Alam, A., Uddin, M. and Yazdifar, H. (2017), "Financing behaviour of R\&D investment in the emerging markets: The role of alliance and financial system", R\&D Management Journal, Forthcoming.

Alam, A., Uddin, M. and Yazdifar, H. (2019), "Institutional determinants of R\&D: Evidence from emerging markets”, Technological Forecasting and Social Change, Vol. 138, pp. 34-44.

Aloui, C. and Nguyen, D. C. (2014), "On the detection of extreme movements and persistent behaviour in Mediterranean stock markets: A wavelet-based approach', Applied Economics, Vol. 46, pp. 2611-2622.

Almeida, A.F.G. and Montes, G.C. (2020), "Effects of crime and violence on business confidence: Evidence from Rio de Janeiro”, Journal of Economic Studies, 47(7), pp. 1669 1688 .

Antoniou, C., Kumar, A. and Maligkris A. (2015), "Terrorism, Emotions and Corporate Policies", SSRN working paper No. 2566740.

Archambeaut, D. and DeZoort, F. T. (2001), "Auditor opinion shopping and the audit committee: An analysis of suspicious auditor switches", International Journal of Auditing, Vol. 5, pp. 33-52.

Arin, K. P., Ciferri, D., and Spagnolo, N. (2008), "The price of terror: The effects of terrorism on Stock Market Return and Volatility”, Economics Letters, Vol. 101, pp. $164-167$.

Bandyopadhyay, S., Sandler, T. and Younas, J. (2014), "Foreign direct investment, aid, and terrorism", Oxford Economic Papers, Vol. 25, pp. 25-50.

Bandyopadhyay, S., Sandler, T. and Younas, J. (2015), “The toll of terrorism", Finance and Development, Vol. 51 No. 2, pp. $26-28$.

Barasa, L., Knoben, J., Vermeulen, P., Kimuyu, P. and Kinyanjui, B. (2017), “Institutions, resources, and innovation in East Africa: A firm level approach”, Research Policy, Vol.46, pp. 280-291. 
Barbosa, N. and Faria, A.P. (2011), "Innovation across Europe: How important are institutional differences?", Research Policy, Vol. 40, pp. 1157-1169.

Bartzokas A. and Mani, S. (2004), "Financial systems, corporate investment in innovation, and venture capital, Edward Elgar Publishing.

Baumeister, R. F., Bratslavsky, E., Finkenauer, C. and Vohs, K. D. (2001), "Bad is Stronger than Good", Review of General Psychology, Vol. 5 No. 4, pp. 323 - 370.

Bertoni, F. and Tykvová, T. (2015), "Does governmental venture capital spur invention and innovation? Evidence from young European biotech companies", Research Policy, Vol. 44, pp. 925-935.

Blomberg, S., Hess, G. D. and Orphanides, A. (2004), "Macroeconomics consequences of terrorism", Journal of Monetary Economics, Vol. 51, pp. 1007-1032.

Brown, J.R., Martinsson, G. and Petersen, B.C. (2013), "Law, stock markets, and innovation”, Journal of Finance, Vol. 68, pp. 1518-1549.

Caplan, B. (2006), “Terrorism: The relevance of the rational choice model”, Pubic Choice, Vol. 128, pp. 91-107.

Carpenter, R. E. and Petersen, B. C. (2002), "Is the growthof small firms constrained by internal finance", The Review of Economics and Statistics, Vol. 84, pp. 298-309.

Chen, Y., Goyal, A., Veeraraghavan, M. and Zolotoy, L. (2020), "Terrorist Attacks, Investor Sentiment and Pricing of Initial Public Offerings", Journal of Corporate Finance, Vol. 65, 101780 .

Chesney, M., Reshetar G. and Karaman M. (2011), “The impact of terrorism on financial markets: An empirical study", Journal of Banking and Finance, Vol. 35, pp. 253-267.

Cheung, K.-Y. and Lin, P. (2004), "Spillover effects of FDI on innovation in China: Evidence from the provincial data", China Economic Review, Vol. 15, pp. 25- 44.

Choi, Y.R., Yoshikawa, T., Zahra, S.A. and Han, B. H. (2014), "Market-oriented institutional change and R\&D investments: Do business groups enhance advantage?", Journal of World Business, Vol. 49, pp. $466-475$. 
Cinar, M. (2017), “The effect of terrorism o economic growth: Panel data approach', Journal of Economics and Business, Vol. 35, No. 1, pp. 97 - 121.

Coggins, B. L. (2015), "Does state failure cause terrorism? An empirical analysis (19992008)", Journal of Conflict Resolution, Vol. 59, pp. 455-483.

Desouza, K. C., Koh, W. T. H. and Ouksel, A. M. (2007), "Information technology, innovation, and the war on terrorism", Technological Forecasting and Social Change, Vol. 74, pp. 125128.

Dutta, S. and Folta, T. B. (2016), "A comparison of the effect of angels and venture capitalists on innovation and value creation", Journal of Business Venturing, Vol. 31, pp. 39-54.

Ehie, I. C. and Olibe, K. (2010), “The effect of R\&D investment on firm value: An examination of US manufacturing and service industries", International Journal of Production Economics, Vol. 128, pp. 127-135.

Erbaş, S. N. (2004), “Ambiguity, transparency, and institutional strength”, IMF Working Paper no WP/04/115.

Flannery, M. and Hankins, K. W. (2013), "Estimating dynamic panels in corporate finance", Journal of Corporate Finance, Vol. 19, pp. 1-19.

Florida, R. L. and Kenney, M. (1988), "Venture capital-financed innovation and technological change in the USA", Research Policy, Vol. 17, pp. 119-137.

Frey, B.S., Luechinger S., 2003. How to fight terrorism: Alternatives to deterrence. Defence and Peace Economics, 14: 237-249.

Freytag, A., Krüger, J.J., Meierrieks, D., Schneider, F., 2011. The origins of terrorism: Cross country estimates of socio-economic determinants of terrorism. European Journal of Political Economy, 27: s5-s16.

Ghazal, R. and Zulkhibri, M. (2015), "Determinants of innovation outputs in developing countries: Evidence from panel data negative binomial approach", Journal of Economic Studies, Vol. 42(2), pp. 237 - 260. 
Gupta S., Clements, B., Bhattacharya, R. and Chakravarti, S. (2004), "Fiscal consequences of armed conflict and terrorism in low- and middle-income countries", European Journal of Political Economy, Vol. 20, pp. 403-421.

Hobbs, J., Schaupp, L. W. and Gingrich., J. (2016), “Terrorism, militarism, and stock returns”, Journal of Financial Crime, Vol. 23, pp. 70-86.

Hottenrott, H. and Peters, B. (2012), "Innovative capability and financing constraints for innovation: More money, more innovation?", Review of Economics and Statistics, Vol. 94, pp. 1126-1142.

Khanna, T. and Palepu, K. (2005), "Spotting institutional voids in emerging markets", Harvard Business School, Back Note, 106-0141-11 August.

Iturriaga, F. G. L. and López-Millán, E. J. (2017), "Institutional framework, corporate ownership structure, and R\&D investment: An international analysis", $R \& D$ Management Journal, Vol. 47, pp. 141-157.

Koh, W. T. H. (2007), "Terrorism and its impact on economic growth and technological innovation”, Technological Forecasting and Social Change, Vol. 74, pp. 129-138.

Kortum, S. and Lerner, J. (2001), "Does venture capital spur innovation? In Entrepreneurial inputs and outcomes: New studies of entrepreneurship in the United States". Emerald G. P. Ltd.

Leaven, L. (2014), “The development of local capital market: Rationale and challenges”, IMF Working Paper No. 234.

Levine, R. (1997), "Financial development and economic growth: Views and agenda", Journal of Economic Literature, Vol. 35, pp. 688-726.

Liu, Y., Miletkov, M.K., Wei, Z. and Yang, T. (2015), "Board independence and firm performance in China", Journal of Corporate Finance, Vol. 30, pp. 223-244.

Manzini, R. and Lazzarotti, V. (2016), "Intellectual property protection mechanisms in collaborative new product development”, R\&D Management Journal, 46, pp. 579-295.

McDonals, R. and Siegel, D. (1986), "The Value of Waiting to Invest", Quarterly Journal of Economics, Vol. 101, pp. $707-727$. 
Mnasri A. and Nechi, S. (2016), "Impact of terrorist attacks on stock market volatility in emerging markets", Emerging Market Review, Vol. 28, pp. 184-202.

Nellis, A. M. and Savage, J. (2012), "Does Watching the News Affect Fear of Terrorism? The Importance of Media Exposure on Terrorism Fear", Crime \& Delinquency, Vol. 58, No. 5 , pp. $748-768$.

Nitsch, V. and Schumacher, D. (2004), “Terrorism and international trade: An empirical investigation”, European Journal of Political Economy, Vol. 20, pp. 423-433.

Pindado, J., Requejo, I. and de la Torre, C. (2014), "Family control, expropriation, and investor protection: A panel data analysis of Western European corporations", Journal of Empirical Finance, Vol. 27, pp. 58-74.

Procasky, W. J. and Ujah, N. U. (2016), “Terrorism and its impact on the cost of debt", Journal of International Money and Finance, Vol. 60, pp. 253-266.

Pucheta-Martinez, M-C., Bel-Oms, I. and Olcina-Sempere, G. (2018), "Female institutional directors on board and firm value", Journal of Business Ethics, Vol. 152, pp. 343-363.

Sandler, T. (2014), "The analytical study of terrorism: Taking stock", Journal of Peace Research, Vol. 51, pp. 257-271.

Sandler, T. and Enders W. (2008), "Economic consequences of terrorism in developed and 30 developing countries: An overview. in Philip Keefer and Norman Loayza (eds.), Terror., Econ. Dev. Pol. Open., Cambridge, Cam. Uni P., 17-47.

Shah, S.H., Hafsa, H. and Sarath, D. (2020), "The impact of foreign direct investment on trade in Pakistan: The moderating role of terrorism", Journal of Economic Studies, Vol. 47, No. 5, pp. $1137-1154$.

Sun, S. L., Chen, V. Z., Sunny, S. A. and Chen, J. (2019), "Venture capital as an innovation ecosystem engineer in an emerging market”, International Business Review, Vol. 28 No. 5, pp. 101485.

Tingbani, I., Okafor, G., Tauringana, V. and Zalata, A. M. (2018), “Terrorism and countrylevel global business failure", Journal of Business Research, Vol. 98, pp. 430 - 440. 
Uddin, M., Chowdhury, A., Zafar, S., Shafique, S. and Liu, J. (2018), "Institutional determinants of inward FDI: Evidence from Pakistan", International Business Review, Vol. 28, No. 2, pp. 344 - 358 .

Wang, Y. A. and Young, M. (2020), “Terrorist Attacks and Investor Risk Preference: Evidence from Mutual Fund Flows”, Journal of Financial Economics, Vol. 137, No. 2, pp. 491 - 514.

Worrall, J. L. (2008), "The effects of local law enforcement block grants on serious crime", Criminal Public Policy. Vol. 7, pp. 325-350.

Worrall, J. L. and Kovandzic, T. V. (2010), "Police levels and crime rate: An instrumental variable approach”, Social Science Research, Vol. 39, pp. 506-516.

Wu, J., Wang, C., Hong, J., Piperopoulos, P. and Zhuo, S. (2016), "Internationalization and innovation performance of emerging market enterprises: The role of host-country institutional development", Journal of World Business, Vol. 51, pp. 251-263.

Xu, Z. (2020), "Economic Policy Uncertainty, Cost of Capital and Corporate Innovation", Journal of Banking and Finance, Vol. 11, pp. 105698. 
Table 1: Summary Statistics

\begin{tabular}{lrrrr}
\hline \hline Variables & Mean & Std. Dev. & Min & Max \\
\hline Innovation & 3.45498 & 0.85801 & 2.00984 & 5.83811 \\
Terrorism & 5.36402 & 0.90017 & 2.13207 & 6.79910 \\
Venture capital & 0.50038 & 0.50019 & 0.00000 & 1.00000 \\
Intellectual property right & 4.44652 & 1.05110 & 1.52198 & 6.66915 \\
Government effectiveness & 3.67978 & 0.76820 & 1.40587 & 6.05409 \\
legal system & 5.53806 & 2.51599 & 0.00000 & 12.0000 \\
FDI and technology transfer & 4.61372 & 0.65012 & 2.35491 & 6.43369 \\
Ease access to loan & 3.11395 & 0.88421 & 1.34723 & 5.74359 \\
Investor protection & 0.56443 & 0.49602 & 0.00000 & 1.00000 \\
Financial market development & 4.16035 & 0.75231 & 2.21366 & 6.23156 \\
\hline \hline Source:Authors' calcution
\end{tabular}

Source: Authors' calculation 
Table 2: Correlation Matrix

\begin{tabular}{|c|c|c|c|c|c|c|c|c|c|c|}
\hline & $(1)$ & $(2)$ & (3) & (4) & $(5)$ & $(6)$ & (7) & $(8)$ & (9) & VIF \\
\hline (1) Innovation & 1 & & & & & & & & & \\
\hline (2) Terrorism & $-0.2124 * * *$ & 1.0000 & & & & & & & & 1.2200 \\
\hline (3) Intellectual Property rights & $0.7865 * * *$ & $0.3835 * * *$ & 1.0000 & & & & & & & 5.4000 \\
\hline (4) Government effectiveness & $0.6879 * * *$ & $-0.3116 * * *$ & $0.83 * * *$ & 1.0000 & & & & & & 3.4900 \\
\hline (5) Legal system & $0.2815 * * *$ & $0.0969 * *$ & $0.2201 * * *$ & $0.2271 * * *$ & 1.0000 & & & & & 1.7200 \\
\hline (6) FDI \& Technology Transfer & $0.5491 * * *$ & $0.259 * * *$ & $0.6669 * * *$ & $0.578^{* * *}$ & $0.2075 * * *$ & 1.0000 & & & & 2.1400 \\
\hline (7) Ease access to loan & $0.5743^{* * *}$ & $0.1251 * * *$ & $0.66 * * *$ & $0.6497 * * *$ & $0.1221 * * *$ & $0.511 * * *$ & 1.0000 & & & 3.2700 \\
\hline (8) Investor protection & $0.2478 * * *$ & 0.0170 & $0.2159 * * *$ & $0.1646 * * *$ & $0.3136 * * *$ & $0.1681^{* * *}$ & $0.1749 * * *$ & 1.0000 & & 1.1600 \\
\hline (9) Financial market development & $0.6855 * * *$ & $-0.261 * *$ & $0.8059 * * *$ & $0.7096 * * *$ & $0.4493 * * *$ & $0.6955^{* * *}$ & $0.773 * * *$ & $0.2879 * * *$ & 1.0000 & 7.1200 \\
\hline
\end{tabular}

Level of Significance 1\%, $5 \%$ and $10 \%$ 
Table 3: GMM-IV Estimation

\begin{tabular}{|c|c|c|c|c|}
\hline & Model (1) & Model(2) & Model(3) & Model(4) \\
\hline \multirow[t]{2}{*}{ Terrorism } & $-0.05786 * * *$ & $-0.05539 * * *$ & $-0.05259 * * *$ & $-0.06074 * * *$ \\
\hline & $(0.01636)$ & $(0.01642)$ & $(0.01575)$ & $(0.01622)$ \\
\hline \multirow[t]{2}{*}{ Terrorism*Developed countries } & & -0.00263 & & \\
\hline & & $(0.00313)$ & & \\
\hline \multirow[t]{2}{*}{ Terrorism*High income countries } & & & -0.03660 & \\
\hline & & & $(0.04324)$ & \\
\hline \multirow[t]{2}{*}{ Terrorism*Venture Capital } & & & & $0.01254 * * *$ \\
\hline & & & & $(0.00358)$ \\
\hline \multirow[t]{2}{*}{ Intellectual property right } & $0.61598 * * *$ & $0.62837^{* * *}$ & $0.64441 * * *$ & $0.62490 * * *$ \\
\hline & $(0.16127)$ & $(0.16897)$ & $(0.18547)$ & $(0.16160)$ \\
\hline \multirow[t]{2}{*}{ Government effectiveness } & -0.02818 & -0.03369 & -0.04256 & -0.04665 \\
\hline & $(0.08930)$ & $(0.09276)$ & (0.10137) & $(0.08977)$ \\
\hline \multirow[t]{2}{*}{ Legal system } & 0.00680 & 0.00709 & 0.00725 & 0.00694 \\
\hline & $(0.00547)$ & $(0.00561)$ & $(0.00577)$ & $(0.00550)$ \\
\hline \multirow[t]{2}{*}{ FDI and technology transfer } & $0.10458 * * *$ & $0.10165^{* * *}$ & $0.09985 * *$ & $0.10119 * *$ \\
\hline & $(0.02980)$ & $(0.03082)$ & $(0.03252)$ & $(0.02987)$ \\
\hline \multirow[t]{2}{*}{ Easy access to loan } & $0.06743 * *$ & $0.06727^{* *}$ & $0.06642 * *$ & $0.05113^{* *}$ \\
\hline & $(0.02112)$ & $(0.02134)$ & $(0.02143)$ & $(0.02170)$ \\
\hline \multirow[t]{2}{*}{ Investor protection } & $0.05967^{* *}$ & $0.05943 * *$ & $0.05964 * *$ & $0.05923 * *$ \\
\hline & $(0.02733)$ & $(0.02764)$ & $(0.02796)$ & $(0.02728)$ \\
\hline \multirow[t]{2}{*}{ Financial market development } & $-0.25497 * * *$ & $-0.25883^{* * *}$ & $-0.26062 * * *$ & $-0.26175^{* * *}$ \\
\hline & (0.05777) & (0.05983) & $(0.06249)$ & $(0.05798)$ \\
\hline Year dummy & Yes & Yes & Yes & Yes \\
\hline Observation & 1327 & 1327 & 1327 & 1327 \\
\hline Underidentification test & 26.594 & 24.689 & 20.398 & 26.596 \\
\hline P-Value & 0.00000 & 0.00000 & 0.00000 & 0.00000 \\
\hline Weak Identification test & 13.991 & 12.846 & 10.439 & 13.981 \\
\hline Over Identification test & 0.058 & 0.033 & 0.023 & 0.053 \\
\hline P-value & 0.8089 & 0.856 & 0.8802 & 0.8174 \\
\hline
\end{tabular}

Standard errors are in parentheses, Level of Significance 1\%, 5\% and 10\% 
Table 4: Panel Cointegration Test

\begin{tabular}{lc}
\hline \hline & \\
Modified Dickey-Fuller test & $1.4719^{*}$ \\
Dickey-Fuller test & $-1.5714^{*}$ \\
Augmented Dickey-Fuller test & $20.1930^{* * *}$ \\
Unadjusted modified Dickey-Fuller test & 0.08800 \\
Unadjusted Dickey-Fuller test & $-2.6313^{* *}$ \\
\hline \hline Notes: Level of significant: ${ }^{*}<.10,{ }^{* *}<.05, * * *<.01$ &
\end{tabular}


Table 5: Robustness Test

\begin{tabular}{|c|c|c|c|c|}
\hline Variables & Model 5 & Model 6 & Model 7 & Model 8 \\
\hline Terrorism & $\begin{array}{l}-0.07372^{* * *} \\
(0.018)\end{array}$ & $\begin{array}{l}-0.11789 * * * \\
(0.016)\end{array}$ & $\begin{array}{l}-0.13262^{* * *} \\
(0.018)\end{array}$ & $\begin{array}{l}-0.08007^{* * *} \\
(0.018)\end{array}$ \\
\hline Terrorism*Developed countries & & $\begin{array}{l}0.02212 * * * \\
(0.001)\end{array}$ & & \\
\hline Terrorism*High Income countries & & & $\begin{array}{l}0.07538^{* * *} \\
(0.006)\end{array}$ & \\
\hline Terrorism*Venture Capital & & & & $\begin{array}{l}0.02863^{* * *} \\
(0.008)\end{array}$ \\
\hline Intellectual property right & $\begin{array}{l}0.55912^{* * *} \\
(0.035)\end{array}$ & $\begin{array}{l}0.31101 * * * \\
(0.031)\end{array}$ & $\begin{array}{l}0.40434 * * * \\
(0.033)\end{array}$ & $\begin{array}{l}0.54447^{* * *} \\
(0.034)\end{array}$ \\
\hline Government Effectiveness & $\begin{array}{l}0.03602 \\
(0.034)\end{array}$ & $\begin{array}{l}0.14537^{* * *} \\
(0.030)\end{array}$ & $\begin{array}{l}0.15969 * * * \\
(0.033)\end{array}$ & $\begin{array}{l}0.03238 \\
(0.034)\end{array}$ \\
\hline Legal system & $\begin{array}{l}0.02677^{* * *} \\
(0.007)\end{array}$ & $\begin{array}{l}0.02043^{* * *} \\
(0.007)\end{array}$ & $\begin{array}{l}0.02975 * * * \\
(0.007)\end{array}$ & $\begin{array}{l}0.02690 * * * \\
(0.007)\end{array}$ \\
\hline FDI and technology transfer & $\begin{array}{l}0.06626^{* *} \\
(0.031)\end{array}$ & $\begin{array}{l}0.16572^{* * *} \\
(0.029)\end{array}$ & $\begin{array}{l}0.07578^{* *} \\
(0.031)\end{array}$ & $\begin{array}{l}0.06112^{* *} \\
(0.031)\end{array}$ \\
\hline Easy access to loan & $\begin{array}{l}0.08719 * * \\
(0.034)\end{array}$ & $\begin{array}{l}0.04652 \\
(0.030)\end{array}$ & $\begin{array}{l}0.01777 \\
(0.035)\end{array}$ & $\begin{array}{l}0.03481 \\
(0.038)\end{array}$ \\
\hline Investor protection & $\begin{array}{l}0.06097^{* *} \\
(0.028)\end{array}$ & $\begin{array}{l}0.04637^{*} \\
(0.024)\end{array}$ & $\begin{array}{l}0.06046^{* *} \\
(0.027)\end{array}$ & $\begin{array}{l}0.05665^{* *} \\
(0.028)\end{array}$ \\
\hline Financial market development & $\begin{array}{l}0.00490 \\
(0.054)\end{array}$ & $\begin{array}{l}-0.00952 \\
(0.048)\end{array}$ & $\begin{array}{l}0.00733 \\
(0.053)\end{array}$ & $\begin{array}{l}0.00393 \\
(0.054)\end{array}$ \\
\hline Year dummy & Yes & Yes & Yes & Yes \\
\hline Observations & 1,327 & 1,327 & 1327 & 1,327 \\
\hline R-squared & 0.66585 & 0.75285 & 0.6969 & 0.66913 \\
\hline F-Test & 136.12(17) & $163.35(18)$ & 140(18) & $129.11(18)$ \\
\hline$P$-value & 0.000 & 0.000 & 0.000 & 0.000 \\
\hline
\end{tabular}


Journal of Economic Studies 


\section{Terrorism, Innovation and Venture Capital}

Table 1: Summary Statistics

\begin{tabular}{lrrrr}
\hline \hline Variables & Mean & Std. Dev. & Min & Max \\
\hline Innovation & 3.45498 & 0.85801 & 2.00984 & 5.83811 \\
Terrorism & 5.36402 & 0.90017 & 2.13207 & 6.79910 \\
Venture capital & 0.50038 & 0.50019 & 0.00000 & 1.00000 \\
Intellectual property right & 4.44652 & 1.05110 & 1.52198 & 6.66915 \\
Government effectiveness & 3.67978 & 0.76820 & 1.40587 & 6.05409 \\
legal system & 5.53806 & 2.51599 & 0.00000 & 12.0000 \\
FDI and technology transfer & 4.61372 & 0.65012 & 2.35491 & 6.43369 \\
Ease access to loan & 3.11395 & 0.88421 & 1.34723 & 5.74359 \\
Investor protection & 0.56443 & 0.49602 & 0.00000 & 1.00000 \\
Financial market development & 4.16035 & 0.75231 & 2.21366 & 6.23156 \\
\hline \hline Source: Authors' calculation
\end{tabular}


Terrorism, Innovation and Venture Capital

Table 2: Correlation Matrix

\begin{tabular}{|c|c|c|c|c|c|c|c|c|c|c|}
\hline & $(1)$ & $(2)$ & (3) & (4) & (5) & (6) & (7) & (8) & (9) & VIF \\
\hline (1) Innovation & 1 & & & & & & & & & \\
\hline (2) Terrorism & $-0.2124 * * *$ & 1.0000 & & & & & & & & 1.2200 \\
\hline (3) Intellectual Property rights & $0.7865 * * *$ & $0.3835 * * *$ & 1.0000 & & & & & & & 5.4000 \\
\hline (4) Government effectiveness & $0.6879 * * *$ & $-0.3116 * * *$ & $0.83^{* * *}$ & 1.0000 & & & & & & 3.4900 \\
\hline (5) Legal system & $0.2815^{* * *}$ & $0.0969 * *$ & $0.2201 * * *$ & $0.2271 * * *$ & 1.0000 & & & & & 1.7200 \\
\hline (6) FDI \& Technology Transfer & $0.5491 * * *$ & $0.259 * * *$ & $0.6669 * * *$ & $0.578 * * *$ & $0.2075 * * *$ & 1.0000 & & & & 2.1400 \\
\hline (7) Ease access to loan & $0.5743 * * *$ & $0.1251 * * *$ & $0.66 * * *$ & $0.6497 * * *$ & $0.1221 * * *$ & $0.511 * * *$ & 1.0000 & & & 3.2700 \\
\hline (8) Investor protection & $0.2478 * * *$ & 0.0170 & $0.2159 * * *$ & $0.1646 * * *$ & $0.3136 * * *$ & $0.1681 * * *$ & $0.1749 * * *$ & 1.0000 & & 1.1600 \\
\hline (9) Financial market development & $0.6855 * * *$ & $-0.261 * *$ & $0.8059 * * *$ & $0.7096 * * *$ & $0.4493 * * *$ & $0.6955 * * *$ & $0.773 * * *$ & $0.2879 * * *$ & 1.0000 & 7.1200 \\
\hline
\end{tabular}

Level of Significance $1 \%, 5 \%$ and $10 \%$ 


\section{Terrorism, Innovation and Venture Capital}

Table 3: GMM-IV estimation

\begin{tabular}{|c|c|c|c|c|}
\hline & Model (1) & Model(2) & Model(3) & Model(4) \\
\hline \multirow[t]{2}{*}{ Terrorism } & $-0.05786 * * *$ & $-0.05539 * * *$ & $-0.05259 * * *$ & $-0.06074 * * *$ \\
\hline & $(0.01636)$ & $(0.01642)$ & $(0.01575)$ & $(0.01622)$ \\
\hline \multirow[t]{2}{*}{ Terrorism*Developed countries } & & -0.00263 & & \\
\hline & & $(0.00313)$ & & \\
\hline \multirow[t]{2}{*}{ Terrorism*High income countries } & & & -0.03660 & \\
\hline & & & $(0.04324)$ & \\
\hline \multirow[t]{2}{*}{ Terrorism*Venture Capital } & & & & $0.01254 * * *$ \\
\hline & & & & $(0.00358)$ \\
\hline \multirow[t]{2}{*}{ Intellectual property right } & $0.61598 * * *$ & $0.62837^{* * *}$ & $0.64441^{* * *}$ & $0.62490 * * *$ \\
\hline & $(0.16127)$ & $(0.16897)$ & $(0.18547)$ & $(0.16160)$ \\
\hline \multirow[t]{2}{*}{ Government effectiveness } & -0.02818 & -0.03369 & -0.04256 & -0.04665 \\
\hline & $(0.08930)$ & $(0.09276)$ & $(0.10137)$ & $(0.08977)$ \\
\hline \multirow[t]{2}{*}{ Legal system } & 0.00680 & 0.00709 & 0.00725 & 0.00694 \\
\hline & $(0.00547)$ & $(0.00561)$ & $(0.00577)$ & $(0.00550)$ \\
\hline \multirow{2}{*}{ FDI and technology transfer } & $0.10458^{* * *}$ & $0.10165^{* * *}$ & $0.09985^{* *}$ & $0.10119 * *$ \\
\hline & $(0.02980)$ & $(0.03082)$ & $(0.03252)$ & $(0.02987)$ \\
\hline \multirow[t]{2}{*}{ Easy access to loan } & $0.06743^{* *}$ & $0.06727 * *$ & $0.06642 * *$ & $0.05113^{* *}$ \\
\hline & $(0.02112)$ & $(0.02134)$ & $(0.02143)$ & $(0.02170)$ \\
\hline \multirow[t]{2}{*}{ Investor protection } & $0.05967 * *$ & $0.05943 * *$ & $0.05964 * *$ & $0.05923 * *$ \\
\hline & $(0.02733)$ & $(0.02764)$ & $(0.02796)$ & $(0.02728)$ \\
\hline \multirow[t]{2}{*}{ Financial market development } & $-0.25497 * * *$ & $-0.25883 * * *$ & $-0.26062 * * *$ & $-0.26175 * * *$ \\
\hline & $(0.05777)$ & $(0.05983)$ & $(0.06249)$ & $(0.05798)$ \\
\hline Year dummy & Yes & Yes & Yes & Yes \\
\hline Observation & 1327 & 1327 & 1327 & 1327 \\
\hline Underidentification test & 26.594 & 24.689 & 20.398 & 26.596 \\
\hline P-Value & 0.00000 & 0.00000 & 0.00000 & 0.00000 \\
\hline Weak Identification test & 13.991 & 12.846 & 10.439 & 13.981 \\
\hline Over Identification test & 0.058 & 0.033 & 0.023 & 0.053 \\
\hline P-value & 0.8089 & 0.856 & 0.8802 & 0.8174 \\
\hline
\end{tabular}

Standard errors are in parentheses, Level of Significance 1\%, 5\% and 10\% 


\section{Terrorism, Innovation and Venture Capital}

Table 4: Panel cointregation test

Modified Dickey-Fuller test

1.4719*

Dickey-Fuller test

$-1.5714^{*}$

Augmented Dickey-Fuller test

$20.1930 * * *$

Unadjusted modified Dickey-Fuller test

0.08800

Unadjusted Dickey-Fuller test

$-2.6313^{* *}$ 


\section{Terrorism, Innovation and Venture Capital}

Table 5: Robustness Test

\begin{tabular}{|c|c|c|c|c|}
\hline Variables & Model 5 & Model 6 & Model 7 & Model 8 \\
\hline Terrorism & $\begin{array}{l}-0.07372 * * * \\
(0.018)\end{array}$ & $\begin{array}{l}-0.11789 * * * \\
(0.016)\end{array}$ & $\begin{array}{l}-0.13262 * * * \\
(0.018)\end{array}$ & $\begin{array}{l}-0.08007^{* * *} \\
(0.018)\end{array}$ \\
\hline Terrorism*Developed countries & & $\begin{array}{l}0.02212^{* * *} \\
(0.001)\end{array}$ & & \\
\hline Terrorism*High Income countries & & & $\begin{array}{l}0.07538^{* * *} \\
(0.006)\end{array}$ & \\
\hline Terrorism*Venture Capital & & & & $\begin{array}{l}0.02863^{* * *} \\
(0.008)\end{array}$ \\
\hline Intellectual property right & $\begin{array}{l}0.55912^{* * *} \\
(0.035)\end{array}$ & $\begin{array}{l}0.31101^{* * *} \\
(0.031)\end{array}$ & $\begin{array}{l}0.40434^{* * *} \\
(0.033)\end{array}$ & $\begin{array}{l}0.54447^{* * *} \\
(0.034)\end{array}$ \\
\hline Government Effectiveness & $\begin{array}{l}0.03602 \\
(0.034)\end{array}$ & $\begin{array}{l}0.14537^{* * *} \\
(0.030)\end{array}$ & $\begin{array}{l}0.15969^{* * *} \\
(0.033)\end{array}$ & $\begin{array}{l}0.03238 \\
(0.034)\end{array}$ \\
\hline Legal system & $\begin{array}{l}0.02677^{* * *} \\
(0.007)\end{array}$ & $\begin{array}{l}0.02043 * * * \\
(0.007)\end{array}$ & $\begin{array}{l}0.02975^{* * *} \\
(0.007)\end{array}$ & $\begin{array}{l}0.02690^{* * *} \\
(0.007)\end{array}$ \\
\hline FDI and technology transfer & $\begin{array}{l}0.06626^{* *} \\
(0.031)\end{array}$ & $\begin{array}{l}0.16572 * * * \\
(0.029)\end{array}$ & $\begin{array}{l}0.07578^{* *} \\
(0.031)\end{array}$ & $\begin{array}{l}0.06112^{* *} \\
(0.031)\end{array}$ \\
\hline Easy access to loan & $\begin{array}{l}0.08719 * * \\
(0.034)\end{array}$ & $\begin{array}{l}0.04652 \\
(0.030)\end{array}$ & $\begin{array}{l}0.01777 \\
(0.035)\end{array}$ & $\begin{array}{l}0.03481 \\
(0.038)\end{array}$ \\
\hline Investor protection & $\begin{array}{l}0.06097^{* *} \\
(0.028)\end{array}$ & $\begin{array}{l}0.04637^{*} \\
(0.024)\end{array}$ & $\begin{array}{l}0.06046^{* *} \\
(0.027)\end{array}$ & $\begin{array}{l}0.05665^{* *} \\
(0.028)\end{array}$ \\
\hline Financial market development & $\begin{array}{l}0.00490 \\
(0.054)\end{array}$ & $\begin{array}{l}-0.00952 \\
(0.048)\end{array}$ & $\begin{array}{l}0.00733 \\
(0.053)\end{array}$ & $\begin{array}{l}0.00393 \\
(0.054)\end{array}$ \\
\hline Year dummy & Yes & Yes & Yes & Yes \\
\hline Observations & 1,327 & 1,327 & 1327 & 1,327 \\
\hline R-squared & 0.66585 & 0.75285 & 0.6969 & 0.66913 \\
\hline F-Test & $136.12(17)$ & $163.35(18)$ & 140(18) & $129.11(18)$ \\
\hline$P$-value & 0.000 & 0.000 & 0.000 & 0.000 \\
\hline
\end{tabular}

